\title{
Growth of Amazon ornamental fish Nannostomus beckfordi larvae (Steindachner, 1876) submitted to different stocking densities and feeding management in captivity conditions
}

\author{
Higo Andrade Abe ${ }^{1}$ (D) | Joel Artur Rodrigues Dias ${ }^{1}$ (D) | Natalino da Costa Sousa ${ }^{1}$ | \\ Márcia Valéria Silva do Couto ${ }^{1}$ | Ryuller Gama Abreu Reis ${ }^{2}$ | \\ Peterson Emmanuel Guimarães Paixão ${ }^{3}$ (D) | Rodrigo Yudi Fujimoto ${ }^{4}$
}

\author{
${ }^{1}$ Post Graduate Program in Animal \\ Science, Federal University of Pará (UFPA), \\ Belem, Brazil \\ ${ }^{2}$ Post Graduate Program in Aquaculture and \\ Tropical Aquatic Resources, Federal Rural \\ University of Amazonia (UFRA), Belem, \\ Brazil \\ ${ }^{3}$ Post Graduate program in Health and \\ Environmental, Tiradentes University \\ (UNIT), Aracaju, Brazil \\ ${ }^{4}$ Brazilian Agricultural Research Corporation \\ (EMBRAPA), Aracaju, Brazil

\section{Correspondence} \\ Rodrigo Yudi Fujimoto, Brazilian Agricultural \\ Research Corporation (EMBRAPA), Av. Beira \\ Mar 3250, Aracaju, Sergipe 49025-040, \\ Brazil. \\ Email: ryfujim@hotmail.com \\ Funding information \\ National Council of Scientific and \\ Technology Development, Grant/Award \\ Number: 305195/2016-6
}

\begin{abstract}
The study evaluated productive performance of larvae Nannostomus beckfordi submitted to feeding management (Experiment one) and different stock density (Experiment two) in captivity conditions. The first experiment evaluated feeding rate (100 and 200 nauplii of artemia larvae ${ }^{-1}$ day $^{-1}$ ) and feeding frequency ( 2 and $4 \times$ per day). Second experiment evaluated different stock density (1, 5, 10, 20, 40 larvae per litre). At the end of 15 days, for both experiment, the survival and productive performance such as total length (TL), final weight (FW), specific development rate (SDR), specific growth rate (SGR), uniformity for weight (UW) uniformity for length $(\mathrm{UL})$ and relative condition factor $(\mathrm{Kr})$ was determined. For the main results, there is no significant difference to the rate and feeding frequency. The stock density has no significant difference for UW, Kr and survival. Nonetheless, a reduction in the TL, FW, SDR, SGR and FW with the increase in density (20 for 40 larvae per litre) was observed. Thus, for this species Nannostomus beckfordi during to initial stage using exogenous feeding, it is recommended 20 larvae per litre fed with 100 nauplii per larvae having two meals per day.
\end{abstract}

\section{KEYWORDS}

characidium, larviculture, pencil fish, production, zootechnical development

\section{1 | INTRODUCTION}

South America has the largest fresh water ichthyofauna on the planet, with more than 5,000 species identified in Brazil. These fish have significant economic value in the international ornamental fish market due to their diverse patterns and colours (Prang, 2008; Reis et al., 2016). The most traded fish are captured in Amazon basin, but this activity has an impact on wild populations (Anjos, Amorim, Siqueira, \& Anjos, 2009; Graça \& Pavanelli, 2008; Tlusty et al., 2013; Zuanon, Salaro, \& Furuya, 2011).
Therefore, the rational and sustainable production of these ornamental species has become an effective option to protect wild stocks and generate income in Brazil. The Lebiasinidae family is among the Amazon species that stand out as having ornamental potential; these fish are distributed from Central America to South America. This family has several species of interest, such as the pencil fish, with its cylindrical body, coloured stripes and superior mouth (Weitzman \& Weitzman, ).

Within this family, Nannostomus beckfordi shows potential in the international market, reaching $3.84 €$ per fish (Allpondsolutions, 2019; Prang, 2008). It is a peaceful fish, with red coloration and a 
long black stripe on its body; it lives on shoal, feeding on microcrustaceans or periphytons and decomposed organic matter (Weitzman $\&$ Weitzman, ). However, there are no scientific reports about its production or management in captivity.

For this reason, to expand the market, it is necessary to develop technological information that determine the ideal management for fish production and reproduction in captivity. Larviculture is one of the critical phases of production in captivity because it encompasses several stress factors, such as changes in water parameters, nutritional deficiencies and infections by pathogens, generating mortality and reducing production (Zuanon et al., 2011).

The feeding frequency, feeding rate and stocking density are important management characteristics for larviculture, influencing survival and performance. Excessive stocking density can promote an excess of nitrogen residue, reducing the water quality and performance, but a low number of individuals implies a bad use of space (Campagnolo \& Ruñer, 2006; Luz \& Santos, 2008). Nonetheless, the ideal feeding frequency leads to better feed conversion, and handling might be reduced (Jomori, Carneiro, \& Martins, 2005; Luz \& Portella, 2005). At the ideal feeding rate, feed waste can be avoided and operational costs can be improved.

Thus, the aim of this study was to evaluate different feeding management strategies (feeding frequencies and feeding rates) and the ideal stocking density for the productive and survival of Nannostomus beckfordi larvae in captivity.

\section{2 | MATERIALS AND METHODS}

Two experiments were carried out using Nannostomus beckfordi larvae. The wild adult fish used as the broodstock were captured and maintained in the laboratory (SISBIO Authorization number 25822). After hatching, the larvae were reared until 8 days. On the first 3 days after hatching, they consumed the yolk sac, and on the next 5 days, they were fed with microalgae and infusoria (Abe, Dias, Cordeiro, Ramos, \& Fujimoto, 2015). Afterwards, the size of the mouth was checked in a microscope to ensure that the fish would be able to prey on Artemia nauplii and start the experiment. The larvae for both experiments had a total length of $0.3 \pm 0.01 \mathrm{~cm}$, but they had no measureable weight, due to their small size. Experimental units were conducted in small containers ( $1 \mathrm{~L}$ ), with a semi-static system without aeration and water exchange (20\% per day after the last feeding).

The first experiment was a $2 \times 2$ factorial design, with two feeding frequencies ( $2 \times$ per day, at 08:00 and 17:00 hours; $4 \times$ per day, at 08:00, 11:00, 14:00 and 17:00 hours), two feeding rates (100 and 200 Artemia nauplii per larvae per day) and four replicates, for 15 days. The stocking density used in this experiment was five larvae per litre.

The second experiment was a completely randomized design, with five stocking densities (1, 5, 10, 20 and 40 larvae per litre) and four replicates per stocking density. The larvae were fed for 15 days, using the best results from the feeding frequency and rate experiment.

Artemia cysts were incubated daily in water with a salinity of $30 \mathrm{~g}$ per litre, at a temperature of $28^{\circ} \mathrm{C}$. After incubation, the cysts were discarded and the nauplii were sampled for quantification. The following water quality parameters were determined every day: oxygen $(\mathrm{mg} / \mathrm{L})$, temperature $\left({ }^{\circ} \mathrm{C}\right)$, electric conductivity $(\mu \mathrm{s} / \mathrm{cm})$ and $\mathrm{pH}$. The total ammonia $(\mathrm{mg} / \mathrm{L}$ ) was determined every 3 days. At the end of the experiment, a biometric process was conducted to determine weight and length in order to evaluate the following productivity performance parameters: total length (TL), final weight (FW), specific growth rate (SGR; In FW or TL-In initial weight or initial length/ days $\times 100$ ) (Lugert, Thaller, Tetens, Schulz, \& Krieter, 2016), relative condition factor ( $\mathrm{Kr}$; expected weight-observed weight) (Le Cren, 1951) survival (S) and uniformity (U) (Furuya, Souza, Furuya, Hayashi, \& Ribeiro, 1998).

$$
U=\frac{x}{X 1} \times 100
$$

U, Uniformity for Length (UL) or Uniformity for Weight (UW); $X$, Total number of fish into experimental unit; $X 1$, Number of fish with Final Weight (FW) or Total length ( $T L$ ) $\pm 20 \%$ inside of the Final Weight Mean or Total Length Mean into experimental unit.

The homoscedasticity and normality of the residuals were tested using the Bartlett and Shapiro-Wilk tests respectively. Data of non-normal distribution were transformed with the arcsine of the square root $(\mathrm{x})$. Afterwards, an analysis of variance was conducted ( $p \leq 0.01$ ), with post hoc Tukey tests ( $p \leq 0.05$ ), using the statistical program Assistat 7.7 (Silva \& Azevedo, 2016).

\section{3 | RESULTS}

In the first experiment, the feeding rate and frequency did not affect the water quality parameters, namely oxygen $(6.2 \pm 0.36 \mathrm{mg} / \mathrm{L})$, temperature $\left(27.6 \pm 0.4^{\circ} \mathrm{C}\right)$, electric conductivity $(315.35 \pm 0.4 \mu \mathrm{s} /$ $\mathrm{cm}), \mathrm{pH}(6.2 \pm 0.3)$ and total ammonia $(0.5 \pm 0.2 \mathrm{mg} / \mathrm{L})$. There was no statistical interaction $(p<0.05)$ between the feeding rate and feeding frequency. The larvae development of the pencil fish, as assessed by the zootechnical parameters, did not differ with the feeding rate or feeding frequency (Table 1 ).

In the second experiment, there was a statistical difference $(p<0.05)$ in some water quality parameters, namely the dissolved oxygen and total ammonia at the largest stocking densities (Table 2).

With regard to the zootechnical parameters, there was no statistical difference $(p>0.05)$ in terms of uniformity, the relative condition factor or survival. However, an increase in the stocking density (20 and 40 larvae/L) promoted a reduction $(p<0.05)$ in productivity in terms of total length, total weight, specific development rate and specific growth rate (Table 3 ).

\section{4 | DISCUSSION}

In the first experiment, water quality parameters showed adequate values for Nannostomus beckfordi, not influencing the zootechnical parameters of the study (Abreu et al., 2014). The feeding frequency (two or four times per day) did not differ between treatments for 
TAB LE 1 Zootechnical parameters (mean values $\pm S D$ ) of pencil fish Nannostomus beckfordi in different rate and feeding frequency

\begin{tabular}{|c|c|c|c|c|c|c|c|}
\hline Variables & \multicolumn{2}{|c|}{ Feeding frequency (times/day) } & \multicolumn{2}{|c|}{ Feeding rate (nauplii/fish/day) } & \multicolumn{3}{|l|}{$p$-value } \\
\hline TL (cm) & $1.23 \pm 0.01$ & $1.26 \pm 0.03$ & $1.25 \pm 0.01$ & $1.33 \pm 0.02$ & 0.5945 & 0.5980 & 0.8586 \\
\hline TW (g) & $0.0146 \pm 0.021$ & $0.0149 \pm 0.013$ & $0.0147 \pm 0.018$ & $0.0182 \pm 0.01$ & 0.2642 & 0.4614 & 0.4514 \\
\hline $\mathrm{SGR}_{(\mathrm{L})}(\% /$ day $)$ & $0.22 \pm 0.02$ & $0.23 \pm 0.01$ & $0.22 \pm 0.02$ & $0.23 \pm 0.02$ & 0.0651 & 0.7809 & 0.0780 \\
\hline $\mathrm{SGR}_{(\mathrm{W})}(\% /$ day $)$ & $0.74 \pm 0.03$ & $0.75 \pm 0.03$ & $0.75 \pm 0.02$ & $0.78 \pm 0.04$ & 0.1424 & 0.0826 & 0.2400 \\
\hline UW (\%) & $64.2 \pm 0.2$ & $68.5 \pm 0.1$ & $66.6 \pm 0.2$ & $62.5 \pm 0.5$ & 0.5987 & 0.6854 & 0.5687 \\
\hline $\mathrm{Kr}$ & $1.00 \pm 0.02$ & $1.00 \pm 0.01$ & $0.98 \pm 0.02$ & $1.00 \pm 0.01$ & 0.0842 & 0.1863 & 0.6515 \\
\hline S (\%) & $92.5 \pm 9.25$ & $95 \pm 9.25$ & $92.5 \pm 9.25$ & $95 \pm 10.35$ & 0.7825 & 0.8694 & 0.7541 \\
\hline
\end{tabular}

Abbreviations: Kr, Relative condition factor; S, Survival; $\mathrm{SGR}_{(\mathrm{L})}$, Specific growth rate for length; $\mathrm{SGR}_{(\mathrm{W})}$, Specific growth rate for weight; TL, Total length; TW, Total weight; UL, Uniformity for length; UW, Uniformity for weight.

TAB LE 2 Mean values and standard deviation of water quality parameters in different stocking densities

\begin{tabular}{llllll} 
Density & DO & Temp & Cond & pH & TA \\
\hline 1 larvae/L & $5.96 \pm 0.02 \mathrm{a}$ & $27.13 \pm 0.05$ & $315.37 \pm 1.47$ & $5.84 \pm 0.005$ & $0.61 \pm 0.007 \mathrm{c}$ \\
\hline larvae/L & $5.93 \pm 0.05 \mathrm{a}$ & $27.06 \pm 0.05$ & $314.07 \pm 0.95$ & $5.85 \pm 0.01$ & $0.63 \pm 0.007 \mathrm{bc}$ \\
\hline 10 larvae/L & $5.86 \pm 0.05 \mathrm{a}$ & $27.06 \pm 0.05$ & $314.37 \pm 4.19$ & $5.85 \pm 0.005$ & $0.72 \pm 0.070 \mathrm{~b}$ \\
\hline 20 larvae/L & $5.7 \pm 0.1 \mathrm{ab}$ & $27.03 \pm 0.05$ & $318.57 \pm 3.32$ & $5.87 \pm 0.01$ & $0.79 \pm 0.035 \mathrm{ab}$ \\
\hline 40 larvae/L & $5.5 \pm 0.2 \mathrm{~b}$ & $27.03 \pm 0.05$ & $318.27 \pm 4.91$ & $5.87 \pm 0.01$ & $0.85 \pm 0.084 \mathrm{a}$ \\
\hline
\end{tabular}

Abbreviations: Cond, Conductivity ( $\mu \mathrm{s} / \mathrm{cm})$; DO, Dissolved oxygen (mg/L); pH and TA, Total ammonia (mg/L); Temp, Temperature ( $\left.{ }^{\circ} \mathrm{C}\right)$. Values within the same column followed by different letter were significantly different $(p<0.05)$.

TA B LE 3 Mean values $\pm S D$ at zootechnical parameters of pencil fish larvae Nannostomus beckfordi in different stocking densities

\begin{tabular}{|c|c|c|c|c|c|c|}
\hline Variables & \multicolumn{5}{|l|}{ Density (larvas/L) } & $p$-value \\
\hline TL (cm) & $1.25 \pm 0.06 \mathrm{~A}$ & $1.22 \pm 0.06 \mathrm{~A}$ & $1.22 \pm 0.02 \mathrm{~A}$ & $1.21 \pm 0.01 \mathrm{AB}$ & $1.11 \pm 0.02 \mathrm{~B}$ & 0.0029 \\
\hline TW (g) & $0.0125 \pm 0.01 \mathrm{~A}$ & $0.0111 \pm 0.02 \mathrm{~A}$ & $0.0120 \pm 0.01 \mathrm{~A}$ & $0.0105 \pm 0.013 \mathrm{AB}$ & $0.0083 \pm 0.005 \mathrm{~B}$ & 0.022 \\
\hline SDR (\%/day) & $0.18 \pm 0.01 \mathrm{~A}$ & $0.18 \pm 0.01 \mathrm{~A}$ & $0.18 \pm 0.01 \mathrm{~A}$ & $0.17 \pm 0.01 \mathrm{~A}$ & $0.16 \pm 0.01 B$ & 0.0008 \\
\hline UW (\%) & $100 \pm 0 \mathrm{~A}$ & $57.5 \pm 9.5 \mathrm{~B}$ & $55 \pm 5.7 \mathrm{~B}$ & $40 \pm 4 B$ & $40 \pm 2 B$ & 0.0001 \\
\hline $\mathrm{Kr}$ & $1.00 \pm 0.03 \mathrm{~A}$ & $0.98 \pm 0.03 \mathrm{~A}$ & $1.00 \pm 0.01 \mathrm{~A}$ & $0.99 \pm 0.03 \mathrm{~A}$ & $0.99 \pm 0.02 \mathrm{~A}$ & 0.7826 \\
\hline S (\%) & $100 \pm 0 \mathrm{~A}$ & $100 \pm 0 \mathrm{~A}$ & $97.5 \pm 5 \mathrm{~A}$ & $97.5 \pm 2.9 \mathrm{~A}$ & $98.12 \pm 2.4 \mathrm{~A}$ & 0.6254 \\
\hline
\end{tabular}

Abbreviations: Kr, Relative condition factor; S, Survival; SDR, Specific development rate; SGR, Specific growth rate; TL, Total length; TW, Total weight; UL, Uniformity for length; UW, Uniformity for weight. Values within the same line followed by different letter were significantly different $(p<0.05)$.

the dependent variables measured. Similar results were observed in Hoplias lacerdae and Lophiosilurus alexandri with the same feeding frequencies during larviculture (Luz \& Portella, 2005; Santos, Pedreira, \& Luz, 2016). However, an increase in the feeding frequency for other two ornamental species, Pyrrhulina brevis and Heros severus, promoted an improvement in performance (Abe et al., 2015, 2016).

The observed result for feeding frequency used could be explained for the mechanical limitation of fish stomach capacity and time for gastric evacuation of pencil fish larvae. Feeding frequency and rate higher than the ideal limits can reduce the efficiency of digestion due to the inefficiency of digestive enzymes caused by the reduction in feed gastrointestinal transit time (Booth, Tucker, Allan, \& Fielder, 2008; Honorato et al., 2016; Lee, Hwang, \& Cho, 2000; Luz \& Portella, 2005; Navarro-Guillén, Engrola, \& Yúfera, 2018; Riche, Haley, Oetker, Garbrecht, \& Garling, 2004).

According to Abe et al. (2015), the ornamental species Pyrrhulina brevis does not show any alteration in growth with different feeding rates, as was also observed in the present study. During larviculture 
of another species, 250 nauplii/larvae was an adequate feeding rate for captivity culture of Heros severus (Abe et al., 2016); however, an increase in the number of Artemia nauplii promoted an improvement in performance, with 900-1600 nauplii being required per larvae of Hoplias lacerdae and Lophiosilurus alexandri (Luz \& Portella, 2005; Santos, Correia \& Luz, 2015).

The same productivity performance at the lowest feeding frequency could be explained by the quiet and sedentary behaviour of the pencil fish Nannostomus beckfordi, as is also observed in L. alexandri and H. lacerdae (Salaro et al., 2011; Travassos, 1959). With this behaviour, the fish avoid wasting energy as there is no need to feed several times per day. The species L. alexandri and $H$. lacerdae have carnivorous feeding habits and need a larger amount of Artemia nauplii than pencil fish (Luz \& Portella, 2002, 2005), probably due to the difference in the intestinal tract ingestion capacity between the species.

Thus, the adequate feeding rate and feeding frequency between species are related to different aspects, such as species' physiology, behaviour, developmental stage, feeding habit and position within the water column (Jomori et al., 2005; Luz \& Portella, 2005; Santos et al.., 2016; Zuanon et al., 2011). The determination of the ideal feeding rate and feeding frequency is important for captivity management, promoting animal welfare, reducing the labour costs, avoiding waste and reducing production costs (Fujimoto et al., 2016; Santos et al., 2015; Zhao et al., 2016).

In the second experiment, there was a reduction in the water quality due to the high stocking density. This was reflected in the largest dissolved oxygen consumption and the increase in nitrogen compounds produced by the fish (Abe et al., 2015; Abe et al., 2016; Luz et al.., 2012; Santos et al., 2015). In addition to the reduction in water quality, there was also a reduction in the productivity performance as stocking density increased. This has been observed in several species, such as Horabagrus brachysoma, Oreochromis niloticus, Trichogaster trichopterus, Pterophyllum scalare, Carassius auratus and Heros severus, due to the behaviour alterations that lead to aggression for feed or territories at high stocking densities (Abe et al., 2016; Barcellos, Nicolaiewsky, Souza, \& Lulhier, 1999; Gonçalves Júnior, Pereira, Matielo, \& Mendonça, 2013; Gonçalves Júnior, Mendonça, Pereira, Matielo, \& Amorim, 2014; Sahoo, Giri, Chandra, \& Sahu, 2010; Syarifuddin \& Kramer, 1996).

For this reason, the poorest water, associated with possible competition, promotes a reduction in larvae performance at high stocking densities. However, in the present study, there was no reduction in the survival or relative condition factor at increased stocking densities; this is important for ornamental fish production due to the trade style of this market (sales by the unit, not by weight). Thus, an increase in density ( 40 larvae/L) can be used by any producer without interfering with fish health and survival.

\section{5 | CONCLUSION}

This is the first report about feeding management for species Nannostomus beckfordi in captivity conditions. Its larviculture (during
15 days) could use 100 artemia nauplii/fish at two feeding frequency having stocking density 20 larvae/L.

\section{ACKNOWLEDGEMENT}

The authors thank National Council of Scientific and Technology Development by financial support to Rodrigo Yudi Fujimoto (305195/2016-6).

\section{ORCID}

Higo Andrade Abe (iD https://orcid.org/0000-0002-5717-9641

Joel Artur Rodrigues Dias (iD https://orcid. org/0000-0001-9751-0207

Peterson Emmanuel Guimarães Paixão (iD https://orcid. org/0000-0002-8949-4232

\section{REFERENCES}

Abe, H. A., Dias, J. A. R., Cordeiro, C. A. M., Ramos, F. M., \& Fujimoto, R. Y. (2015). Pyrrhulina brevis (Steindachner, 1876) como uma nova opção para a piscicultura ornamental nacional: larvicultura. Boletim do Instituto Da Pesca, 41(1), 113-122.

Abe, H. A., Dias, J. A. R., Reis, R. G. A., Sousa, C. N., Ramos, F. M., \& Fujimoto, R. Y. (2016). Manejo alimentar e densidade de estocagem na larvicultura do peixe ornamental amazônico Heros severus. Boletim do Instituto De Pesca, 42(3), 514-522.

Abreu, J. S., Brinn, R. P., Gomes, L. C., Mccomb, D. M., Baldisserotto, B., Zaiden, S. F., \& Marcon, J. L. (2014). Effect of beta 1, 3 glucan in stress responses of the pencilfish (Nannostomus trifasciatus) during transport within the rio negro basin. Neotropical Ichthyology, 12(3), 623-628.

Allpondsolutions (2019) https://www.allpondsolutions.co.uk/gold-penci Ifish/. Accessed in 06/03/2019.

Anjos, H. D. B., Amorim, R. M. S., Siqueira, J. A., \& Anjos, C. R. (2009). Exportação de peixes ornamentais do estado do Amazonas, bacia amazônica Brazil. Boletim do Instituto Da Pesca, 35(2), 259-274.

Barcellos, L. G., Nicolaiewsky, S., De Souza, S. G., \& Lulhier, F. (1999). The effects of stocking density and social interaction on acute stress response in Nile tilapia Oreochromis niloticus (L.) fingerlings. Aquaculture Research, 30(11-12), 887-892.

Booth, M. A., Tucker, B. J., Allan, G. L., \& Fielder, D. S. (2008). Effect of feeding regime and fish size on weight gain, feed intake and gastric evacuation in juvenile Australian snapper Pagrus auratus. Aquaculture, 282(1-4), 104-110.

Campagnolo, R., \& Ruñer, A. P. O. (2006). Sobrevivência e crescimento de larvas de surubim, Pseudoplatystoma corruscans (pisces, pimelodidae), em diferentes densidades de estocagem. Acta Scientiarum. Animal Sciences, 28(2), 231-237.

Fujimoto, R. Y., Santos, R. F. B., Dias, H. M., Ramos, F. M., Silva, D. J. F., \& Honorato, C. A. (2016). Feeding frequency on the production viability of production and quantitative descriptors of parasitism in angelfish. Ciência Rural, 46(2), 304-309.

Furuya, W. M., Souza, S. R., Furuya, V. S. B., Hayashi, C., \& Ribeiro, R. P. (1998). Dietas peletizada e extrusada para machos revertidos de tilápia do Nilo (Oreochromis niloticus) na fase de terminação. Ciência Rural, 28(3), 483-487.

Gonçalves Júnior, L. P., Pereira, S. L., Matielo, M. D., \& Mendonça, P. P. (2013). Efeito da densidade de estocagem no desenvolvimento 
inicial do acará bandeira (Pterophyllum scalare). Arquivo Brasileiro De Medicina Veterinária E Zootecnia, 65(1), 1176-1182.

Gonçalves Júnior, P. L., Mendonça, P. P., Pereira, S. L., Matielo, M. D., \& Amorim, I. R. S. (2014). Densidade de estocagem durante a larvicultura do kinguio. Boletim do Instituto Da Pesca, 40(4), 597-604.

Graça, W. J., \& Pavanelli, S. (2008). Characidium heirmostigmata, a new characidiin fish (characiformes: Crenuchidae) from the upper rio Paraná basin. Brazil. Neotropical Ichthyology, 6(1), 53-56.

Honorato, C. A., Almeida, L. C., Camilo, R. Y., Moraes, G., Nunes, C. D. S., \& Carneiro, D. J. (2016). Dietary carbohydrate and food processing affect the digestive physiology of Piaractus mesopotamicus. Aquaculture Nutrition., 22(1), 857-864.

Jomori, R. K., Carneiro, D. J., \& Martins, M. I. E. G. (2005). Economic evaluation of Piaractus mesopotamicus juvenile production in different rearing systems. Aquaculture, 234(1), 175-183.

Le Cre, E. D., (1951). The length-weight relationship and seasonal cycle in gonad weight and condition in the perch (Perca fluviatilis). Journal of Animal Ecology, 20(2), 201-219.

Lee, S. M., Hwang, U. G., \& Cho, S. H. (2000). Effects of feeding frequency and dietary moisture content on growth, body composition and gastric evacuation of juvenile Korean rockfish (Sebastes schlegeli). Aquaculture, 187(3-4), 399-409.

Lugert, V., Thaller, G., Tetens, J., Schulz, C., \& Krieter, J. (2016). A review on fish growth calculation: Multiple functions in fish production and their specific application. Reviews in Aquaculture, 8(1), 30-42.

Luz, R. K., \& Portella, M. C. (2002). Larvicultura de trairão (Hoplias lacerdae) em água doce e água salinizada. Revista Brasileira De Zootecnia, 31(2), 829-834.

Luz, R. K., \& Portella, M. C. (2005). Freqüencia alimentar na larvicultura do trairão (Hoplias lacerdae). Revista Brasileira De Zootecnia, 34(5), 1442-1448.

Luz, R. K., \& Santos, J. C. E. (2008). Densidade de estocagem e salinidade da água na larvicultura do pacamã. Pesquisa Agropecuária Brasileira, 43(7), 903-909.

Luz, R. K., Silva, W. S., Melillo filho, R., Santos, A. E. H., Rodrigues, L. A., Takata, R., ... Turra, E. M. (2012). Stocking density in the larviculture of Nile tilapia in saline water. Revista Brasileira De Zootecnia, 41(12), 2385-2389.

Navarro-Guillén, C., Engrola, S., \& Yúfera, M. (2018). Daily dynamic of digestive processes in Senegalese sole (Solea senegalensis) larvae and post-larvae. Aquaculture, 493, 100-106.

Prang, G. (2008). An industry analysis of the freshwater ornamental fishery with particular reference to the supply of Brazilian freshwater ornamentals to the UK market. Scientific Magazine Uakari, 3(1), 7-52.

Reis, R. E., Albert, J. S., Dario, F., Mincarone, M. M., Petry, P., \& Rocha, L. A. (2016). Fish biodiversity and conservation in south America. Journal of Fish Biology, 89(1), 12-47.

Riche, M., Haley, D. I., Oetker, M., Garbrecht, S., \& Garling, D. L. (2004). Effect of feeding frequency on gastric evacuation and the return of appetite in tilapia Oreochromis niloticus (L.). Aquaculture, 234(1-4), 657-673.
Sahoo, S. K., Giri, S. S., Chandra, S., \& Sahu, A. K. (2010). Stocking density-dependent growth and survival of asian sun catfish, Horabagrus brachysoma (Gunther 1861) larvae. Journal of Applied Ichthyology, 26(1), 609-611.

Salaro, A. L., Tavares, M. M., Chaves, W., Campelo, D. A. V., Zuanon, J. A. S., \& Luz, R. K. (2011). Feed training of juvenile giant trahira under different light intensities. Revista Brasileira De Zootecnia., 40(11), 2290-2293.

Santos, J. C. E., Correia, S. E., \& Luz, R. K. (2015). Effect of daily artemia nauplii concentrations during juvenile production of Lophiosilurus alexandri. Boletim Instituto da Pesca, 41, 771-776.

Santos, J. C. E., Pedreira, M. M., \& Luz, R. K. (2016). Frequência alimentar na larvicultura de pacamã. Revista Caatinga, 29(2), 512-518.

Silva, F. A. S., \& Azevedo, C. A. V. (2016). The Assistat Software Version 7.7 and its use in the analysis of experimental data. African Journal of Agricultural Research, 11(39), 3733-3740.

Syarifuddin, S., \& Kramer, D. L. (1996). The effect of group size on space use and aggression at a concentrated food source in blue gouramis, Trichogaster trichopterus (pisces: Belontiidae). Environmental Biology of Fishes, 46(3), 289-296.

Tlusty, M. F., Rhyne, A. L., Kaufman, L., Hutchins, M., Reid, G. M., Andrews, C., \& Dowd, S. (2013). Opportunities for public aquariums to increase the sustainability of the aquatic animal trade. Zoo Biology, 32(1), 1-12.

Travassos, H. (1959). Nótula sobre o pacamã. Lophiosilurus alexandri steindachner, 1876. Atas Da Sociedade De Biologia do Rio De Janeiro, 4, 1-2.

Weitzman, M., \& Weitzman, S. H. (2003). Family lebiasinidae (pencil fishes). In R. E. Reis, S. O. Kullander, \& C. J. Ferraris Jr (Eds.), Check list of the freshwater fishes of South and Central America (pp. 241-250). Porto Alegre, Brazil: Edipucrs.

Zhao, S., Han, D., Zhu, X., Jin, J., Yang, Y., \& Xie, S. (2016). Effects of feeding frequency and dietary protein levels on juvenile allogynogenetic gibel carp (Carassius auratus gibelio) var. cas iii: Growth, feed utilization and serum free essential amino acids dynamics. Aquaculture Research, 47(1), 290-303.

Zuanon, J. A. S., Salaro, A. L., \& Furuya, W. M. (2011). Produção e nutrição de peixes ornamentais. Revista Brasileira De Zootecnia, 40, 165-174.

How to cite this article: Abe HA, Dias JAR, Sousa NC, et al. Growth of Amazon ornamental fish Nannostomus beckfordi larvae (Steindachner, 1876) submitted to different stocking densities and feeding management in captivity conditions. Aquac Res. 2019;00:1-5. https://doi.org/10.1111/are.14108 